\title{
Frost resistance in alpine woody plants
}

\section{Gilbert Neuner*}

Unit Functional Plant Biology, Institute of Botany, University of Innsbruck, Innsbruck, Austria

\section{Edited by:}

Karen Tanino, University of

Saskatchewan, Canada

\section{Reviewed by:}

Rajeev Arora, lowa State University, USA

Danielle Way, Western University, Canada

\section{${ }^{*}$ Correspondence:}

Gilbert Neuner, Unit Functional Plant Biology, Institute of Botany, University of Innsbruck, Sternwartestraße 15, A-6020 Innsbruck, Austria

e-mail: gilbert.neuner@uibk.ac.at
This report provides a brief review of key findings related to frost resistance in alpine woody plant species, summarizes data on their frost resistance, highlights the importance of freeze avoidance mechanisms, and indicates areas of future research. Freezing temperatures are possible throughout the whole growing period in the alpine life zone. Frost severity, comprised of both intensity and duration, becomes greater with increasing elevation and, there is also a greater probability, that small statured woody plants, may be insulated by snow cover. Several frost survival mechanisms have evolved in woody alpine plants in response to these environmental conditions. Examples of tolerance to extracellular freezing and freeze dehydration, life cycles that allow species to escape frost, and freeze avoidance mechanisms can all be found. Despite their specific adaption to the alpine environment, frost damage can occur in spring, while all alpine woody plants have a low risk of frost damage in winter. Experimental evidence indicates that premature deacclimation in Pinus cembra in the spring, and a limited ability of many species of alpine woody shrubs to rapidly reacclimate when they lose snow cover, resulting in reduced levels of frost resistance in the spring, may be particularly critical under the projected changes in climate. In this review, frost resistance and specific frost survival mechanisms of different organs (leaves, stems, vegetative and reproductive over-wintering buds, flowers, and fruits) and tissues are compared. The seasonal dynamics of frost resistance of leaves of trees, as opposed to woody shrubs, is also discussed. The ability of some tissues and organs to avoid freezing by supercooling, as visualized by high resolution infrared thermography, are also provided. Collectively, the report provides a review of the complex and diverse ways that woody plants survive in the frost dominated environment of the alpine life zone.

Keywords: ice susceptibility, freezing avoidance, frost dehardening, frost hardening, supercooling

\section{INTRODUCTION}

Freezing temperatures are a major environmental stress factor in the alpine life zone and in the treeline ecotone. Woody plants in these areas are frequently exposed to conditions that can result in frost damage. Frost resistance of tree species present at the alpine treeline in temperate climates has been addressed several times in prior reviews (Tranquillini, 1979; Neuner, 2007; Körner, 2012). Less information is available for other woody alpine species that do not grow to the height of trees. Additionally, frost resistance has often been exclusively studied in leaves and detailed seasonal records have been reported. Frost survival of an individual, however, will also depend, if not more so, on the survival of other organs, such as bud and stem tissues. The degree of frost resistance and the underlying frost survival mechanisms of these essential organs are, in many cases, still unknown. The same is true for the effect of frost on reproductive tissues, which can have a dramatic impact on overall reproductive success. Improvements in imaging methods to study the freezing processes in plants, such as infrared differential thermal analysis (IDTA; Hacker and Neuner, 2007, 2008; Hacker et al., 2008; Neuner et al., 2010; Kuprian et al., 2014), has led to significant advances in our current understanding of ice propagation, ice barriers, and supercooling in plants. IDTA can provide more precise information on tissue-specific mechanisms of frost survival and on the basis of frost damage. Additionally, the development of field portable frost chambers (Neuner et al., 1999b; Taschler and Neuner, 2004; Buchner and Neuner, 2009), provides the ability to simulate night frosts and study recovery and recuperation under natural conditions, even though the use of the chambers may not be able to mimic a true radiation frost (Frederiks et al., 2012). These combined approaches can provide results that are more ecologically relevant for the prediction of future scenarios of plant survival and distribution. This may become even more important in view of global warming, as alpine environments are categorized as highly vulnerable ecosystems under climate change projections (Theurillat and Guisan, 2001; Byars et al., 2007).

Frost-induced drought and photodamage, typical parameters of winter stress (Neuner et al., 1999a) that often occur along with freezing stress, are not addressed in this review, although they may also be critically important for winter survival of woody species. Processes related to cold acclimation have been reviewed by Pearce (1999), Thomashow (1999), and Xin and Browse (2000) are also not the primary focus of this review.

\section{FREEZING TEMPERATURES IN THE TEMPERATE ALPINE ZONE}

The temperate alpine life zone extends from treeline at approximately $2000 \mathrm{~m}$ (spread over several $100 \mathrm{~m}$ of altitude) up to the altitudinal limit of closed vegetation, around $3480 \mathrm{~m}$ (Grabherr et al., 1995; Körner, 2003). The ultimate limit of individual 
higher plant life in the European Alps was reported to be at $4507 \mathrm{~m}$ (Körner, 2011). Woody species, of course, have a lower upper distribution boundary, which is around $3000 \mathrm{~m}$ (Salix herbacea, Landolt, 1992), than herbaceous plants. Freezing temperatures can occur throughout the whole year in the temperate alpine zone and their severity increases significantly with elevation. The seasonal change in monthly minimum air temperatures (2003-2013) of seven meteorological stations in the Austrian Central Alps is shown in comparison to a low land site (Innsbruck $578 \mathrm{~m}$; Figure 1) in order to highlight the characteristics of the alpine life zone with respect to freezing temperatures. The meteorological stations within the alpine life zone are located along an elevational gradient of approximately $1500 \mathrm{~m}$. While a considerable frost free period is evident (May till September) at the lowland site, a characteristic of the alpine life zone is the lack of a frost free period, as freezing temperature can occur virtually throughout the whole year. At an elevation of $1942 \mathrm{~m}$, freezing temperatures $\left(-4.7^{\circ} \mathrm{C}\right.$ in June and $-1.0^{\circ} \mathrm{C}$, July/August) can occur during the summer months, while at $3437 \mathrm{~m}$, temperatures can drop substantially lower $(-14.7$ June and $-10.5^{\circ} \mathrm{C}$ July/August; Figure 1 inset). In midwinter, air temperatures can drop to -26.1 (February) at $1942 \mathrm{~m}$ and to $-31.5^{\circ} \mathrm{C}$ at $3437 \mathrm{~m}$. The adiabatic lapse rate from these air temperature minima is $-0.7 \mathrm{~K} \cdot 100 \mathrm{~m}^{-1}$. In addition to the increase in frost severity with elevation, the frequency of freezing events also rises significantly with increasing elevation within the alpine life zone (Taschler and Neuner, 2004; Larcher and Wagner, 2009; Neuner and Hacker, 2012).

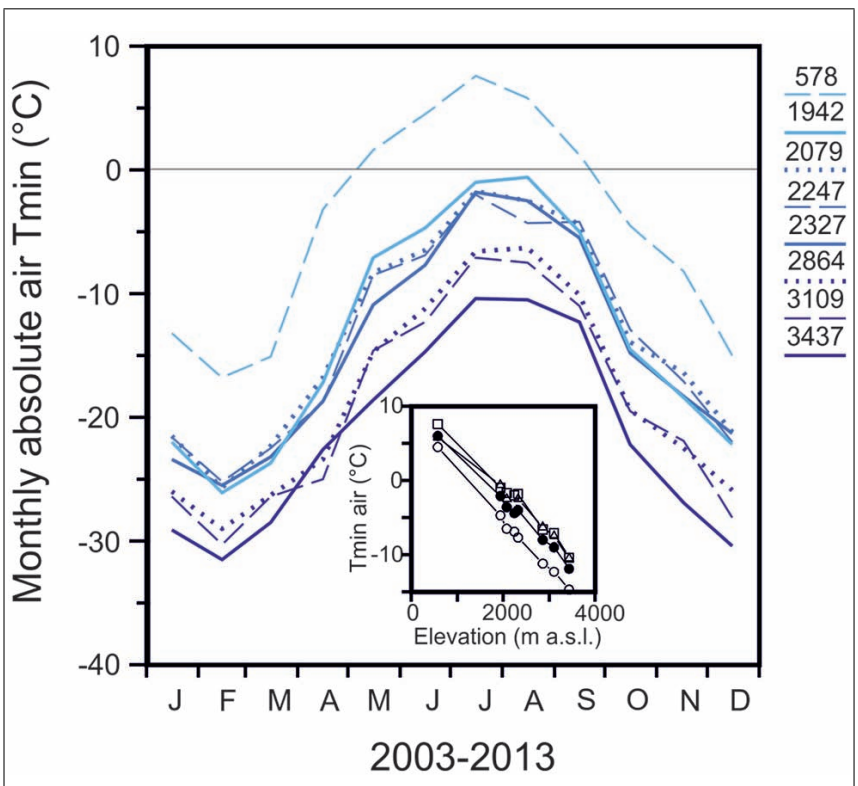

FIGURE 1 | Monthly absolute air temperature minima obtained for the period 2003-2013 from records of meteorological stations located at the indicated elevations in the Central European Alps of Austria [Innsbruck-University (578 m), Obergurgl (1942 m), Patscherkofel (2247 m), Galzig (2079 m), Ischgl-Idalpe (2327 m), Pitztaler Gletscher (2864 m), Sonnblick (3109 m), Brunnenkogel (3437 m)]. Inset: Reduction of absolute air temperature minimum with increasing elevation during the snow free period in $(O)$ June, $(\triangle)$ July, $(\square)$ August and $(\mathbf{O})$ the summer mean (all data from ZAMG, Austria).

\section{PLANT MINIMUM TEMPERATURES}

It is possible for the temperature of plant material to be lower than air temperature. Specifically, the net radiation balance of leaves can become negative during clear, calm nights due to long-wave radiative heat loss (Stefan-Boltzmann-law) which cools the leaves below air temperature. This is the basis for dew or surface ice formation but can also result in the freezing of plant tissues despite an air temperature above $0^{\circ} \mathrm{C}$. Leaves of conifers were found to be up to $9.3 \mathrm{~K}$ colder than air temperature at treeline (Tranquillini, 1958, 3-8 K: Jordan and Smith, 1994). Air temperature may exhibit an extreme drop down to $-37.4^{\circ} \mathrm{C}$ (Mt. Sonnblick, 3105 m, 1.1.1905, Austria; Central Institute for Meteorology and Geodynamics, Austria) in alpine areas of Austria during the winter. Winter temperature minima the last ten years (2003-2013) have ranged between $-26.1^{\circ} \mathrm{C}(1942 \mathrm{~m})$ and $-31.5^{\circ} \mathrm{C}(3437 \mathrm{~m})$. Based on these data, leaf temperatures down to approximately -35 to $-46^{\circ} \mathrm{C}$ may occur in exposed plants during clear and calm winter nights (Neuner, 2007). Radiative cooling conditions in June may account for leaf temperatures down to approximately -14 to $-24^{\circ} \mathrm{C}$ in July and down to approximately -10 to $-20^{\circ} \mathrm{C}$ in August.

In summer, mean leaf temperature minima decrease with increasing elevation at a rate of $0.4 \mathrm{~K} .100 \mathrm{~m}^{-1}$ (Neuner and Hacker, 2012) which is less than the adiabatic lapse rate of air $\left(0.7 \mathrm{~K} .100 \mathrm{~m}^{-1}\right)$. The difference may be explained by the change in growth forms and snow protection of plants during cold spells in summer. Bioclimate temperatures lower than $0^{\circ} \mathrm{C}$ during the snow free period were found to occur at a frequency of $20 \%$ at the treeline $(1950 \mathrm{~m})$, while at $3450 \mathrm{~m}$ night frost frequency increased to $69 \%$ (Larcher and Wagner, 2009).

In addition to the severity and frequency of freezing temperatures, cooling and warming rates also appear to be important for frost survival of woody plants. Natural cooling rates below $0^{\circ} \mathrm{C}$ in leaves of alpine plants did not exceed $-2 \mathrm{~K} \cdot \mathrm{h}^{-1}$ (mean rate: $-0.3 \mathrm{~K} . \mathrm{h}^{-1}$; Neuner and Buchner, 2012). Exceptionally more rapid cooling rates, however, cannot be fully excluded, as reported by Körner (2012). In northern Sweden, temperature drops below $0^{\circ} \mathrm{C}$ of up to $-15 \mathrm{~K}$ within minutes were recorded at the upper border of cold air drained during a temperature inversion. This rapid temperature drop resulted in the mortality of Betula pubescens buds that otherwise would have survived exposure to freezing temperatures down to $-70^{\circ} \mathrm{C}$ under moderate cooling rates (Körner, 2012).

Snow cover significantly mitigates temperature minima and the rate of temperature change to which plants are exposed. Important factors contributing to of the degree of thermal insulation are the thickness of the snow pack (Figure 2) and its consistency (Kuhn, 2012). While protective effects of snow cover have long been recognized (Sakai and Larcher, 1987), thermal insulation by snow may also be crucially important for protecting plants from low freezing temperatures during episodes of freezing temperatures in summer (Larcher and Wagner, 2009; Ladinig et al., 2013). A certain degree of thermal insulation is possible by snow coverage for dwarf shrubs and young trees in the summer months but will be lost at a certain stage of tree development when a specific tree height is reached. The establishment of tree seedlings and young plants may even be favored at growing sites with sufficient snow 


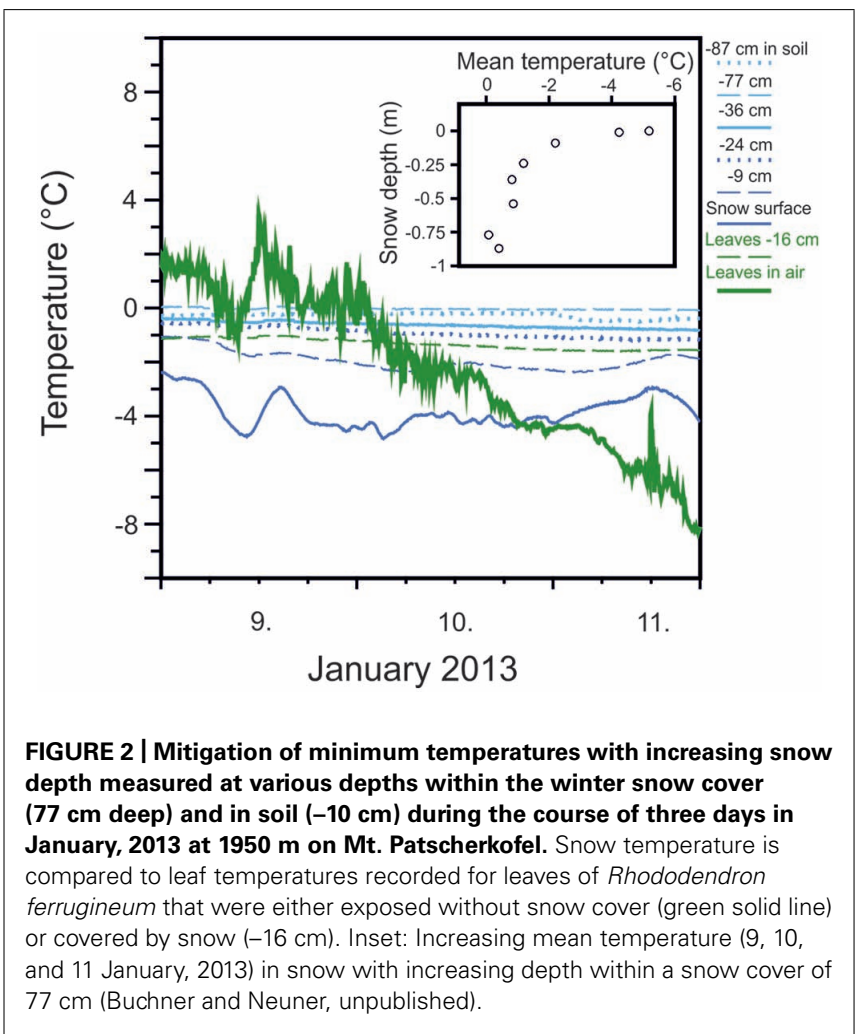

coverage. On the other hand, being tall as a tree actually reduces the risk of frost injury during summer radiation frosts compared to small statured woody plants because radiative freezing during clear nights is negatively correlated with tree height (Körner, 2012).

\section{ORGAN-SPECIFIC RISK OF FROST DAMAGE IN WOODY ALPINE PLANTS}

In addition to minimum temperatures, the duration of a frost event and the rate of temperature change that can occur at specific parts of the year, play an essential role in determining the potential risk of frost injury to plants and the actual killing temperature of any specific plant species. Frost survival of individual woody plants is difficult to assess as frost resistance can differ greatly in various organs and tissues. For instance, the most frost susceptible organs in woody alpine plants in the summer are reproductive shoots $\left(-4.6^{\circ} \mathrm{C}\right)$ followed by developing leaves $\left(-5.0^{\circ} \mathrm{C}\right)$, fully expanded leaves $\left(-6.6^{\circ} \mathrm{C}\right)$, vegetative buds $\left(-7.3^{\circ} \mathrm{C}\right)$, and then xylem tissue $\left(-10.8^{\circ} \mathrm{C}\right.$; Figure 3$)$. While hardly any data exist for roots, they are commonly recognized as being the most susceptible to frost injury (Sakai and Larcher, 1987).

A survey of the frost resistance of different organs and tissues of 15 species of woody plants are presented in Table 1. The selected species comprise four trees, two tall shrubs, and nine dwarf shrubs that all have different vertical distributions in the Central European Alps.

\section{REPRODUCTIVE SHOOTS IN SUMMER}

Various strategies have evolved in alpine plants to prevent frost damage to reproductive shoots. To date, the only alpine plant

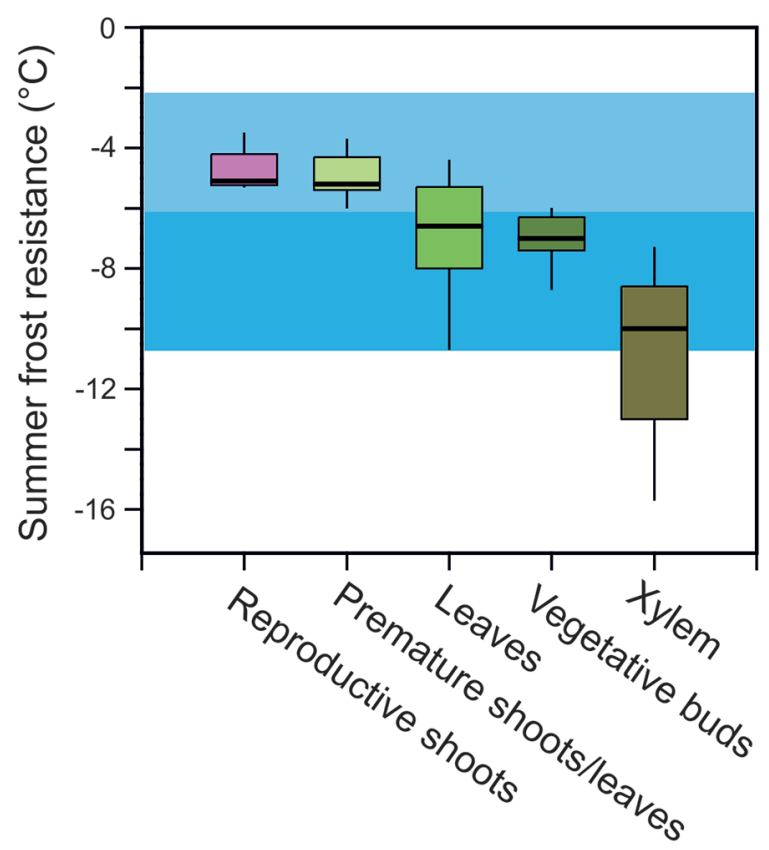

FIGURE 3 | Frost resistance $\left(\mathrm{LT}_{\mathrm{i}} / \mathrm{LT}_{10} ;{ }^{\circ} \mathrm{C}\right)$ of different organs of woody alpine plant species listed in Table 1 assessed during summer [data compiled from: Sakai and Larcher (1987), Taschler and Neuner (2004), Ladinig et al. (2013), and Neuner et al. (unpublished)]. Air temperature minima in June (blue horizontal bar) and July and August (light blue horizontal bar) as recorded at the upper distribution boundary of the species (2100-2800 m) in the years 2003-2013 (see legend to Figure 1). $\mathrm{LT}_{\mathrm{i}} / \mathrm{LT} \mathrm{T}_{10}=$ freezing temperature causing initial and $10 \%$ frost damage. Box plots show the median, and the 25 and $75 \%$ quartiles, respectively, given by the lower and upper edges of boxes. Whiskers show the 95\% confidence interval. Outliers are not shown.

species found to actually exhibit freezing tolerance in its reproductive shoots is the nival herb Ranunculus glacialis (Ladinig et al., 2013). All other species have been reported to be freezing sensitive, i.e. exhibit injury if ice forms in their reproductive shoots (Ladinig et al., 2013). In contrast, fully developed vegetative parts of woody alpine plant species, such as stem, bark, and leaves can tolerate extracellular ice formation down to a species-specific low temperature during the summer months without damage (Taschler and Neuner, 2004). Once ice formation is initiated somewhere inside a vegetative part of a plant, it can propagate rapidly (up to $27 \mathrm{~cm} . \mathrm{s}^{-1}$ ) throughout the vascular system in all plant parts colder than $0^{\circ} \mathrm{C}$ (Hacker and Neuner, 2007, 2008; Hacker et al., 2008).

Freezing sensitive reproductive shoots of some alpine species have evolved supercooling strategies aided by ice barriers in order to prevent frost injury. The ice barriers prevent the spread of ice from frozen plant parts into the supercooled organs or tissues. In cushion plants, the ice barriers are thermal rather than physical. The spread of ice from one flower stalk to the next is interrupted by the thermal insulation that exists inside the cushion portion of the plant from which the individual flower stalks arise, maintaining the cushion warmer than $0^{\circ} \mathrm{C}$ during the course of a night frost event (Hacker et al., 2011). Structural ice barriers have also been found in some 
Table 1 | Characteristics of the surveyed species, after Landolt (1992).

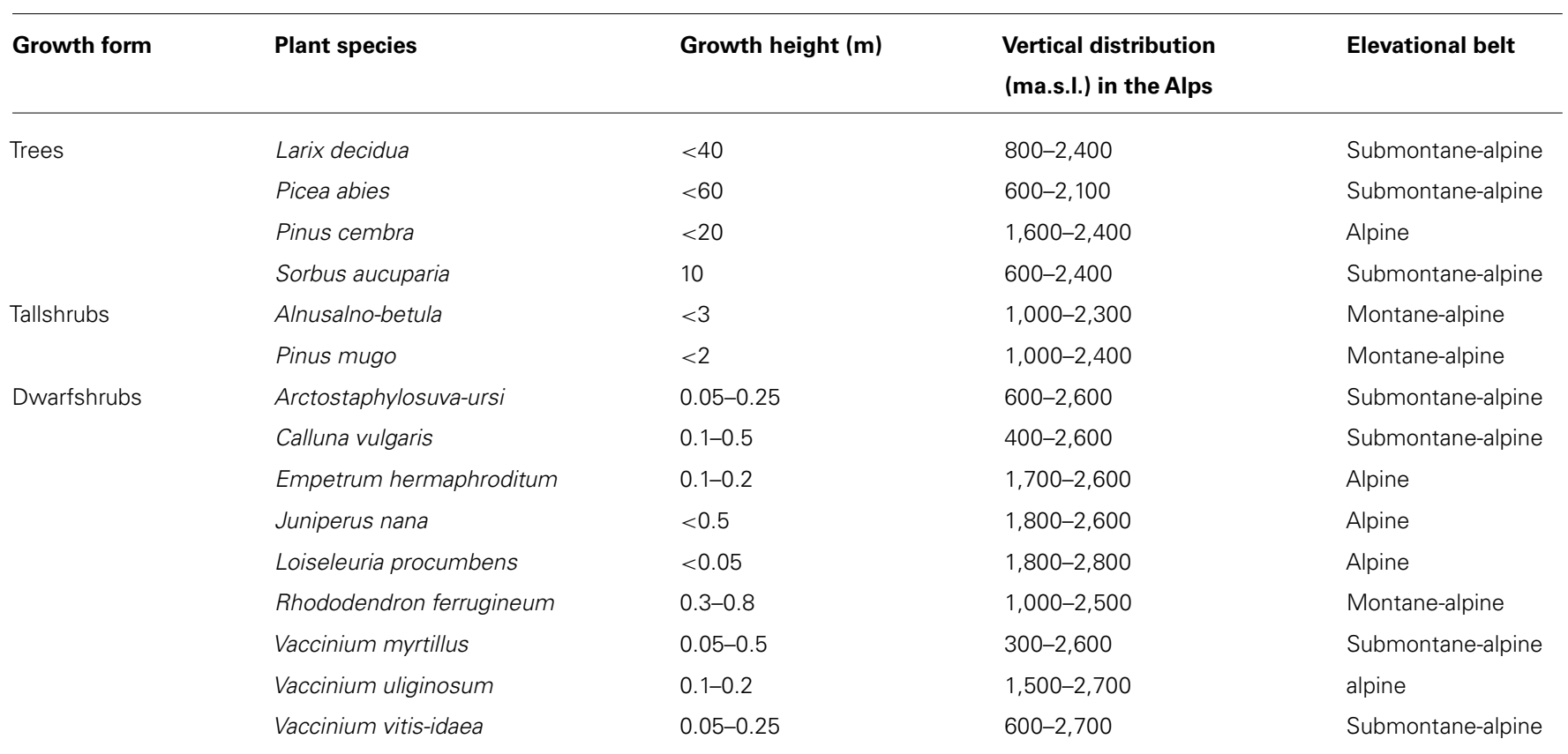

species of woody plants (Workmaster et al., 1999; Carter et al., 2001; Kuprian et al., 2014). The specific nature of these physical barriers is currently under investigation. It appears that some unique aspect of the anatomical structure in the portion of the stem subtending the reproductive shoot prevents ice propagation into the shoot, allowing it to remain supercooled.

The probability of frost damage to reproductive shoots becomes greater and greater with increasing elevation and has been observed to occur on a recurrent basis in nature (Ladinig et al., 2013). Scarce information exists, however, about the frost resistance of reproductive tissues in woody alpine species (Table 2 ). The frost resistance of reproductive tissues of two woody alpine species (Rhododendron ferrugineum and Loiseleuria procumbens) was recently investigated (Ladinig et al., 2013). During anthesis and fruiting in the summer months, the reproductive shoots of these species were freezing sensitive and significantly less frost resistant than their ice tolerant vegetative shoots (Ladinig et al., 2013). Ice propagation into the reproductive shoots of $R$. ferrugineum via the vegetative shoot is not prevented by any ice barrier and any ice formation in the plant results in frost damage to reproductive tissues (Neuner and Hacker, 2012), which can occur at $-3.3^{\circ} \mathrm{C}$ (Ladinig et al., 2013). In contrast, anatomical ice barriers efficiently prevent ice intrusion into the supercooled reproductive shoots of $L$. procumbens and other woody species in the summer months (Kuprian et al., 2014). This allows reproductive shoots to remain in a supercooled state during a night frost and survive completely undamaged despite freezing of the vegetative parts. While vegetative parts froze between -4.7 and $-5.7^{\circ} \mathrm{C}$, reproductive shoots were able to supercool down to a range of $-7.2^{\circ} \mathrm{C}$ to $-18.2^{\circ} \mathrm{C}$, and in some cases even below $-22^{\circ} \mathrm{C}$ (Kuprian et al., 2014). This mechanism of freeze avoidance has been shown to be effective in preventing frost injury during various stages of reproductive development (bud, anthesis, and fruit) throughout the alpine summer. Supercooling was $100 \%$ effective in preventing frost damage to reproductive shoots in the woody shrub species Calluna vulgaris and Empetrum hermaphroditum, while the ice barrier failed to prevent ice entrance in L. procumbens in $13 \%$ of the total observations (Kuprian et al., 2014). The frost survival mechanism of reproductive shoots in summer months in other alpine woody species is currently unknown.

\section{REPRODUCTIVE OVERWINTERING BUDS}

Overwintering reproductive buds of many angiosperm woody plants survive freezing temperatures during the winter months by supercooling (Sakai and Larcher, 1987). Reproductive bud tissues are isolated from acropetally advancing ice in the subtending stem by the presence of ice barriers that restrict ice growth into the meristem. Such a frost survival mechanism has been documented in reproductive buds of $R$. ferrugineum using IDTA, where single flowers within the floral bud freeze intracellularly at temperatures between -16 and $-25^{\circ} \mathrm{C}$, while ice formation in the stem and leaves occurs at $-4^{\circ} \mathrm{C}$ (Neuner and Hacker, 2012). Midwinter air temperatures can drop below the supercooling temperature of overwintering reproductive buds of $R$. ferrugineum $\left(-16\right.$ to $-25^{\circ} \mathrm{C}$; Larcher and Wagner, 2004) when plants are not insulated by snow cover and causes severe frost damage (personal communication, J. Wagner). Supercooling also appears to be the primary mechanism of frost survival in over-wintering reproductive buds of Vaccinium vitis-idea (Figure 4). The frost survival mechanism of reproductive overwintering buds in most other woody alpine plants has not been examined. While frost damage to reproductive buds is not critical to individual survival, 


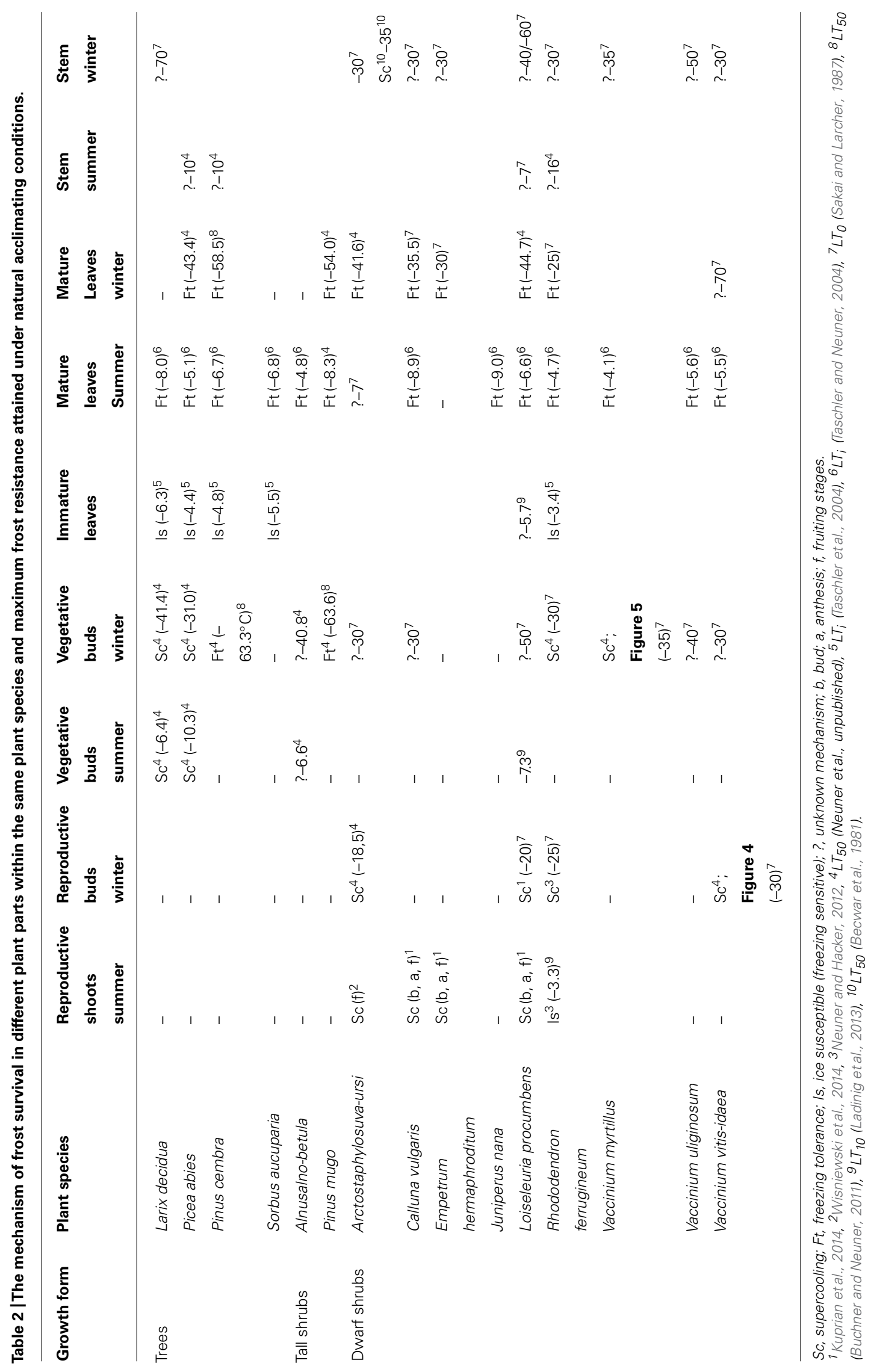



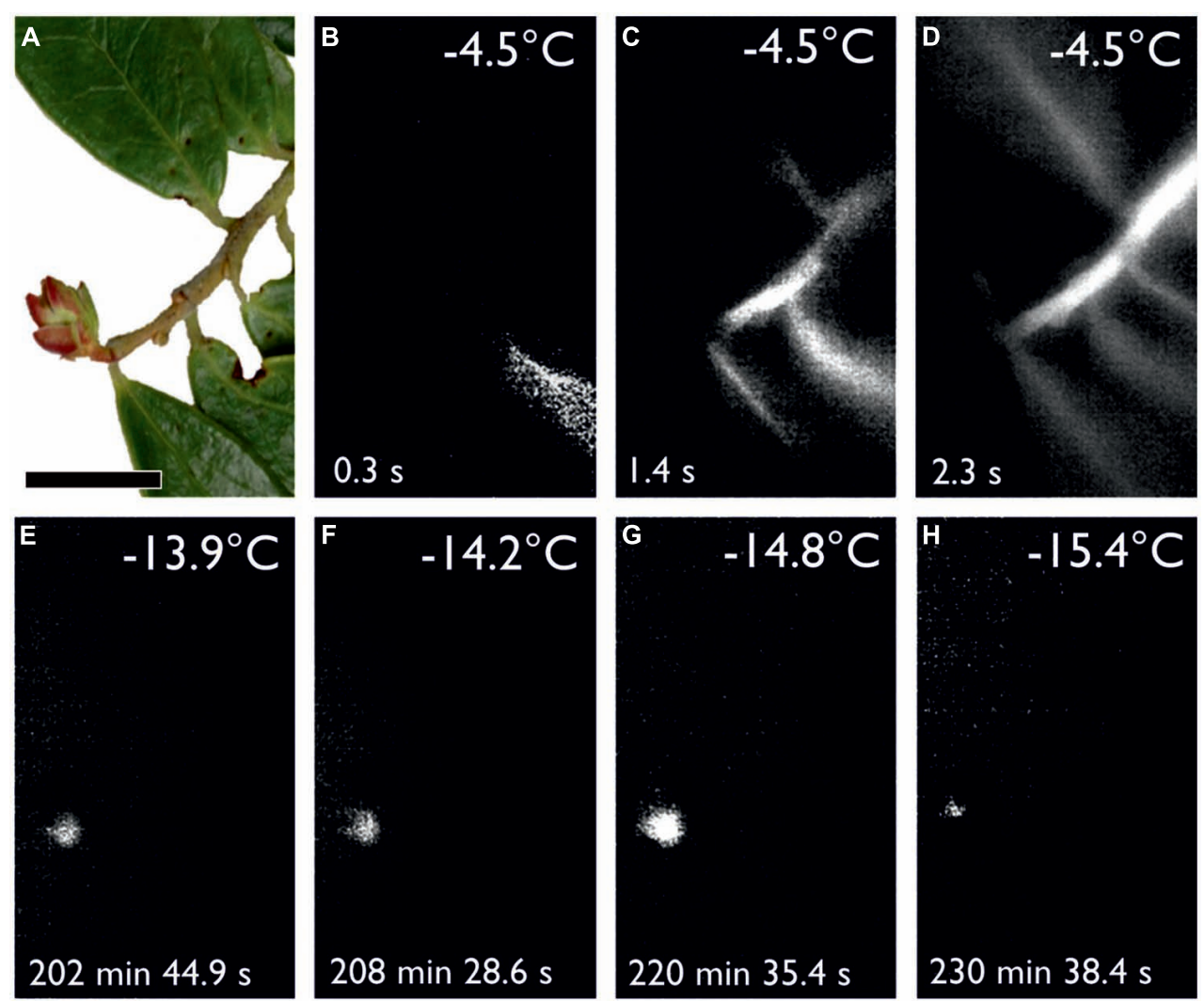

FIGURE 4 | (A) Digital image of a shoot bearing a reproductive winter bud of Vaccinium vitis-idaea sampled on Mt. Patscherkofel (2010 m a.s.l.) during snow melt on 12.5.2014 before exposure to a controlled freezing treatment with a cooling rate of $3 \mathrm{~K} / \mathrm{h}$ from $+2^{\circ} \mathrm{C}$ down to $-22.0^{\circ} \mathrm{C}$ (horizontal black bar width $=1 \mathrm{~cm}$ ). (B-D) IDTA images show initial ice nucleation in a single leaf at $-4.5^{\circ} \mathrm{C}$. Ice propagates unhindered throughout the leaf into the vegetative shoot and the attached leaves but not into the reproductive bud. (E-H) The

sequence of IDTA images shows the occurrence of independent freezing events in the reproductive bud at temperatures ranging from -13.9 to $-15.4^{\circ} \mathrm{C}$, which are lower than the temperature at which ice nucleation occurred in the vegetative part of the shoot. Freezing is visualized by a brightening in the image, while unfrozen areas remain black. The time elapsed after the occurrence of ice nucleation in the leaf is indicated in the bottom left corner of each image (Kuprian and Neuner, unpublished).

it can strongly influence the reproductive success of a species. In this regard, the deleterious impact of frost injury on sexual plant reproduction has been shown to become significantly greater with increasing elevation, and at higher elevations may even impair successful seed development in most years (Ladinig et al., 2013).

\section{VEGETATIVE BUDS}

Primordia within dormant vegetative buds have been reported to survive freezing temperatures by either extra-organ freezing or freezing tolerance (Sakai and Larcher, 1987). In vegetative buds exhibiting extra-organ freezing, ice formation does not occur in the primordial tissue itself. Water within primordial tissues remains supercooled, down to a particular species-specific and developmentally determined temperature. When freezing does occur, however, it is a lethal event. During supercooling, water migrates from the supercooled primordial tissue to specific extracellular locations in the stem and/or bud scales, thus inducing dehydrative conditions in the primordial tissues. This process has been termed extra-organ freezing (Ishikawa and Sakai, 1982). Three types of extra-organ freezing have been postulated, defined by the mode of freeze dehydration and the dehydration tolerance of bud primordia (Sakai and Larcher, 1987): In Type I, primordia are fully dehydration tolerant, become fully freeze dehydrated, and no freezable water remains. Such primordia can survive immersion in $\mathrm{LN}_{2}\left(-80^{\circ} \mathrm{C}\right)$. In Type II, primordia experience freeze-induced dehydration due to the migration of water from the primordia to the remote sites of extracellular ice but have a limited level of dehydration tolerance and are thus injured at temperatures in the range of -35 to $-50^{\circ} \mathrm{C}$. Type III primordia become only partially dehydrated, thus freezable water remains inside the primordial cells and cells are killed when temperatures exceed the extent of supercooling $\left(-25\right.$ and $\left.-30^{\circ} \mathrm{C}\right)$ and the primordia experience intracellular ice formation; which is a lethal event.

For woody alpine species, a paucity of information exists on the frost survival mechanism of dormant buds. Extra-organ freezing was initially reported in conifers for Abies homolepis and A. balsamea (Sakai, 1978) and appears to occur in species in the genera Abies, Picea, and Larix (Sakai and Larcher, 1987; Zwiazek et al., 2001). In contrast, ice seems to form innocuously in Pinus shoot primordia, without any large degree of supercooling, at the same time ice forms in stem tissues; with frost injury occurring at 
temperatures much lower than when ice formation initially occurs (Ide et al., 1998). Preliminary results on alpine conifers also suggest that similar genus-specific mechanisms of frost survival are present in their dormant vegetative buds (Table 2). P. cembra and $P$. mugo tolerate extracellular ice formation in their vegetative buds while $P$. abies and $L$. decidua seem to survive by supercooling and extra-organ freezing.

Even less information exists for dormant buds of angiosperm species. Although information on the frost resistance of angiosperm vegetative buds is available (Sakai and Larcher, 1987), the frost survival mechanism of vegetative bud primordia is still little understood. In one study (Ishikawa et al., 1997), lateral vegetative buds of Acer japonicum were reported to exhibit Type I extraorgan freezing, i.e. primordia become fully dehydrated due to the loss of water to sites of extracellular ice outside of the primordial tissues and the primordia are extremely dehydration tolerant. Type II extra-organ freezing was suggested to occur in dormant apple buds (Pramsohler and Neuner, 2013). There is also a report that the vegetative buds of the angiosperm, Pyrus syriaca, exhibit Type III extra-organ freezing (Rajashekar and Burke, 1978). Recent observations on dormant vegetative buds of Rhododendron ferrugineum also indicate that they supercool (Zimmermann and Neuner, unpublished). Supercooling, as a mechanism of frost resistance, also seems to be apparent in vegetative buds of V. myrtillus (Figure 5). Based on data obtained from IDTA images, stems in winter initially froze between -3.2 and $-3.5^{\circ} \mathrm{C}$ during a controlled freezing experiment, while buds appeared to freeze in the range of -18.2 to $-22.0^{\circ} \mathrm{C}$. Separate freezing events located in the resting buds can be clearly recognized. This is still a higher freezing temperature, however, than the reported midwinter frost resistance of $-35^{\circ} \mathrm{C}$ for $V$. myrtillus buds (Sakai and Larcher, 1987). Since all of the samples used in the controlled freezing experiments were dug out from under snow, it is presumed that the moderate temperature conditions below the snow are the reason for the lower frost resistance observed in the IDTA.

Winter frost resistance of dormant buds of woody alpine shrubs ranges from -30 to $-50^{\circ} \mathrm{C}$ (see Table 2 ) which is similar to the range found in trees, with the exception of $P$. cembra whose buds have been shown to acquire an $\mathrm{LT}_{50}$ of $-63.6^{\circ} \mathrm{C}$ in midwinter, which is more cold hardy than the leaves $\left(-58.5^{\circ} \mathrm{C}\right.$; Buchner and Neuner, 2011). In fact, the frost resistance of resting buds of conifers generally seems to be higher than that of leaves. In a global survey of maximum winter frost resistance in conifers (Bannister and Neuner, 2001) inhabiting climatic zones 7 and greater, 56\% had a level of frost resistance in vegetative buds that was equal to the frost resistance of leaves, and 33\% had vegetative buds that were more frost resistant than leaves. Only $11 \%$ had leaves that were more cold hardy than buds. No conclusion can be drawn, however, from the scarce data available for angiosperms.

\section{JUVENILE LEAVES AND SHOOTS}

Young, developing juvenile leaves and shoots are typically freezing sensitive and exhibit frost damage close to the temperature at which ice formation occurs (Taschler et al., 2004; Ladinig et al., 2013). Moderate night frosts during the annual period of growth in June have been repeatedly observed to cause severe frost damage to sprouting shoots and leaves of subalpine woody species in the European Alps (Kerner, 1869; Matuszkiewicz, 1977; Christersson et al., 1987; Taschler et al., 2004; Neuner, 2007; Neuner and Beikircher, 2010). It is very clear that current year growth is highly susceptible to frost damage. Initial frost damage $\left(\mathrm{LT}_{\mathrm{i}}\right)$ can be observed after exposure to $-3.4^{\circ} \mathrm{C}$ (Rhododendron ferrugineum), $-4.4^{\circ} \mathrm{C}$ (Picea abies), $-4.8^{\circ} \mathrm{C}$ (Pinus cembra), $-5.5^{\circ} \mathrm{C}$ (Sorbus aucuparia), and $-6.3^{\circ} \mathrm{C}$ (Larix decidua). These temperatures are likely to occur in the treeline ecotone during the annual periods of growth (Taschler et al., 2004). Only P. cembra seems capable of escaping natural frost damage due to a later onset of sprouting (late June to July), when potential air temperature minima are much more moderate and insufficient to cause frost injury.

Importantly, after a loss of current year's growth, conifers do not foliate again until the next growing season. While this type of frost injury and subsequent delayed growth did not appear to threaten the survival of trees (Tranquillini, 1979; Sakai and Larcher, 1987; Gross et al., 1991), it was suggested that it may partly contribute to the distorted growth of small trees in the krummholz belt (Tranquillini, 1979).

\section{MATURE LEAVES}

In contrast to all other plant parts, frost resistance in leaves of woody alpine species has been frequently studied. Unlike developing leaves and shoots, the frost resistance of mature leaves generally appears to exceed environmental demand. Mature leaves of alpine woody species are ice tolerant. The temperature at which initial frost damage $\left(\mathrm{LT}_{\mathrm{i}}\right)$ occurs in the summer is species-specific but generally occurs in the range of -4.1 to $-9.0^{\circ} \mathrm{C}$ (Table 2 ; Taschler and Neuner, 2004). Evergreen leaves of woody species can attain a midwinter frost resistance of -26.0 to $-58.5^{\circ} \mathrm{C}$ when cold acclimated under natural conditions. A maximum frost resistance in needles of as low as $-90^{\circ} \mathrm{C}$ has been reported for the pine species, P. cembra and P. mugo (LT 0 ; Sakai and Okada, 1971) which suggests that species that occupy the alpine region in the European Alps may have the capacity to develop a greater level of frost resistance under the proper acclimating conditions.

Seasonal data on frost resistance ( $\mathrm{LT}_{10}$ monthly means) of leaves of the evergreen shrub Rhododendron ferrugineum and the coniferous trees, Picea abies and Pinus cembra, determined by various authors throughout the $20^{\text {th }}$ century at the same study site (Mt. Patscherkofel, 1935/36: Ulmer, 1937; 1942/43/44: Pisek and Schiessl, 1947; 1965/66/67: Schwarz, 1970; 1993/94/95/96: Neuner et al., 1999b) are shown in Figure 6. The seasonal amplitude of frost resistance varies in a species-specific manner. Rhododendron shrubs develop a lower level of midwinter freezing resistance than the coniferous trees. The seasonal amplitude of frost resistance of leaves in the evergreen trees $P$. abies and P. cembra is approximately $40-50 \mathrm{~K}$, but in shrubs it is much less, ranging between 15 and $35 \mathrm{~K}$ (Figure 7).

In contrast to trees, smaller statured woody shrubs are usually covered by thermally insulating snow and are thus exposed to more moderate temperature conditions during the winter. Early snowfalls in autumn can interfere with the natural process of cold acclimation (Neuner et al., 1999b), reducing the maximum frost 

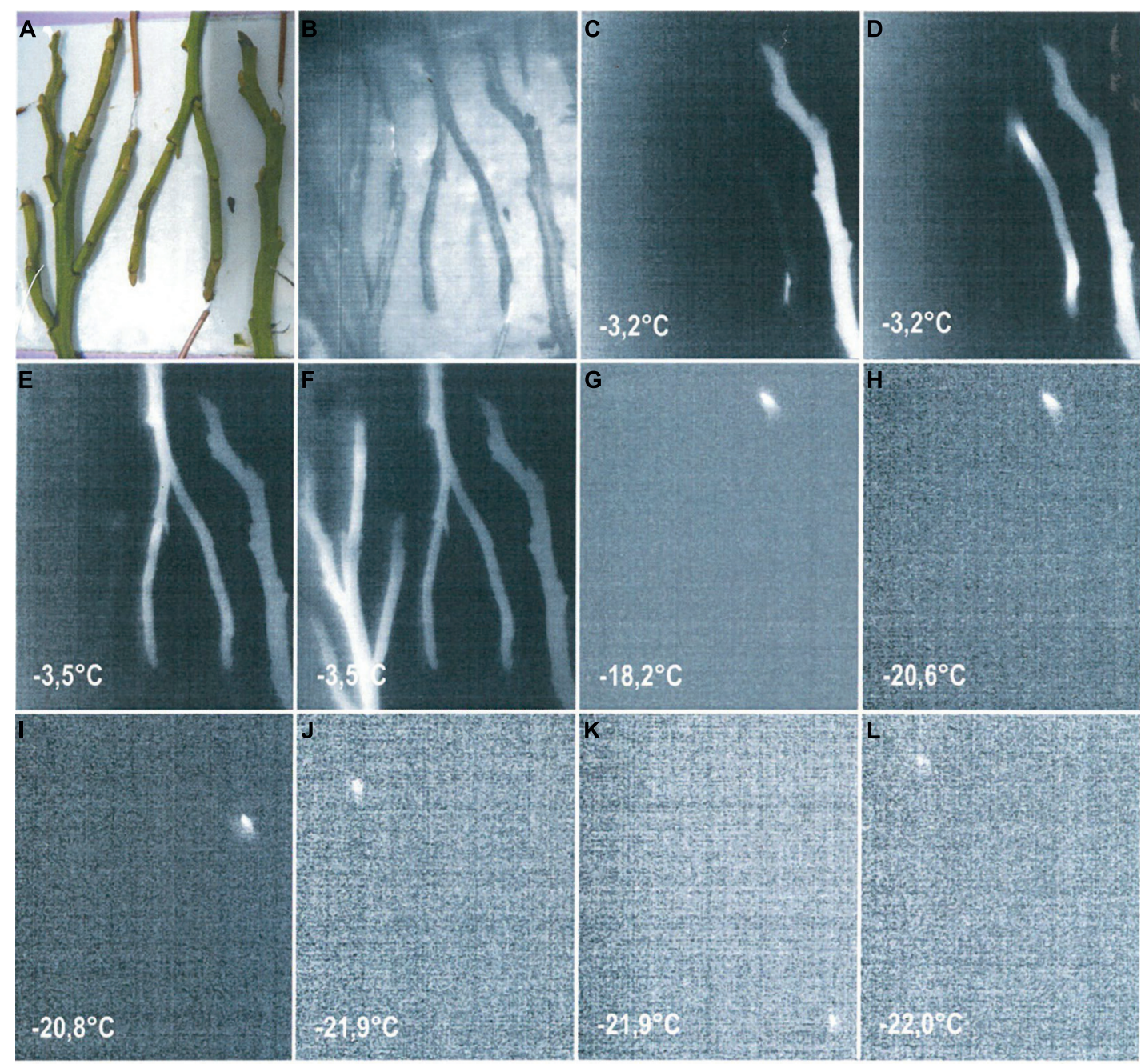

FIGURE 5 | (A) Digital image of shoots of Vaccinium myrtillus sampled in winter (17.1.2014) from below a thick snow cover before exposure to a controlled freezing treatment with a cooling rate of $3 \mathrm{~K} / \mathrm{h}$. (B-F) IDTA images show ice propagation in the stems occurring at temperatures between -3.2 and $-3.5^{\circ} \mathrm{C}$. Ice propagates unhindered throughout the whole shoot.

resistance attained in midwinter. Additionally, moderate temperature conditions beneath snow cover in subalpine environments have been shown to be conducive to frost dehardening (Sakai and Larcher, 1987; Neuner et al., 1999b). The maximum frost resistance of leaves of $R$. ferrugineum collected in January at the same site but in different years throughout the last century was between -14.0 and $-29.5^{\circ} \mathrm{C}\left(\mathrm{LT}_{10}\right.$; Neuner et al., 1999b). During mild winters with early snow melt, plants do not frost harden to the same extent as when they remain exposed until midwinter (Neuner et al., 1999b). This variability in frost resistance can also be observed in leaves collected below a thick snow vs. leaves collected from exposed branches on the same sampling date and site (Table 3). Differences in frost resistance of up to $13 \mathrm{~K}$ could be observed. The most prominent environmental differences affecting exposed vs. snow-covered leaves are the severity of freezing temperatures, the irradiation climate, and plant water status.
(G-L) Single bud meristems froze independently at temperatures ranging from -18.2 and $-22.0^{\circ} \mathrm{C}$, which are significantly lower than the temperature at which ice was formation was initiated in the shoot. Freezing is visualized by a brightening in the image, while unfrozen areas remain black (Miller and Neuner, unpublished).
Woody plants that are exposed experience much lower freezing temperatures under natural irradiation and daylength conditions and quite often are exposed to severe winter drought. In contrast, the insulating properties of snow significantly mitigates freezing temperatures, keeping them close or slightly below $0^{\circ} \mathrm{C}$. Additionally, under $15 \mathrm{~cm}$ of snow, PPFD can be nearly to completely eliminated and the darkness may protect plants from dehardening in response to long days in May. Additionally, a thick snow pack is the best way to escape winter drought (Sakai and Larcher, 1987). Firstly, water loss is nearly eliminated when plants are covered by a thick layer of snow and secondly, snow cover gets successively wetter during the course of winter (Kuhn, 2012) allowing to restore water deficits by direct water uptake from the wet snow.

Similarly, frost resistance in leaves of $P$. abies, which in cold winter periods approaches $-45^{\circ} \mathrm{C}$ at the treeline, was only $-30^{\circ} \mathrm{C}$ during the exceptionally warm winter of 1987/88 (Körner, 2012). 


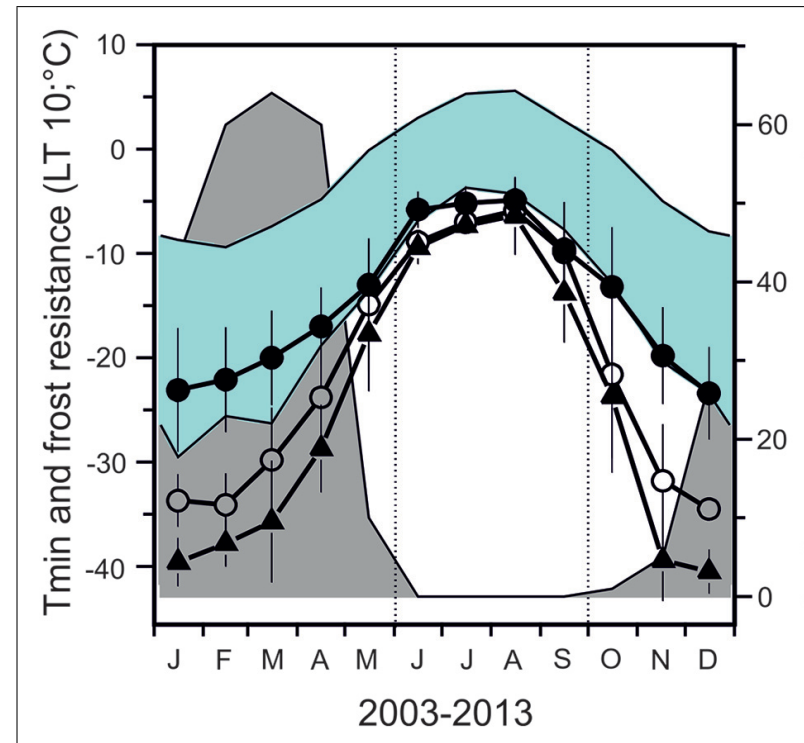

FIGURE 6 | Monthly mean values of frost resistance ( $\left.\mathrm{LT}_{10}\right)$ of leaves of the evergreen shrub $(O)$ Rhododendron ferrugineum and of the coniferous trees, $(O)$ Picea abies and $(\Delta)$ Pinus cembra. Values were calculated from data obtained throughout the entire $20^{\text {th }}$ century (data from: 1935/36: Ulmer, 1937; 1942/43/44: Pisek and Schiessl, 1947; 1965/66/67: Schwarz, 1970; 1993/94/95/96: Neuner et al., 1999b). Monthly mean and absolute air temperature minima (blue area) and monthly minimum of snow depth data (gray area) were obtained from a 46 year measurement period (ZAMG, Meteorological Station Mt. Patscherkofel $2247 \mathrm{~m}$ a.s.l.) close to the sampling site on Mt. Patscherkofel.

Furthermore, plants of the same species cold acclimate to a lesser extent at a lower elevation (P. abies:-10 K, V. vitis-idea:-19 K) compared to plants located at treeline (see Table 3). This corroborates the findings of Gross (1989 cited in Körner, 2012) who reported an increase in the frost resistance of $P$. abies leaves from $-30^{\circ} \mathrm{C}$ at $950 \mathrm{~m}$ to $-35^{\circ} \mathrm{C}$ at timberline in the central Alps.

The risk of frost damage changes significantly with season, which can be derived from the relationship between the temperatures representing frost resistance vs. temperature minima (see Figure 6). Leaves of trees at the alpine treeline have a low risk of frost damage at midwinter. This has been previously recognized, as tree-sized woody plants were suggested to exhibit a sufficient level of freezing resistance to avoid freeze damage (Larcher, 1985; Hadley and Smith, 1987; Gross et al., 1991; Perkins et al., 1991; Havranek and Tranquillini, 1995; Perkins and Adams, 1995; Körner, 2012). Regarding shrubs, given that timely snow falls provide a thermal insulation, the risk of freeze injury must be also considered rather low in winter. This may not be the case, however, if the pattern, duration, and timing of snow cover changes in future.

The overall level of risk for freezing injury in the spring is very different than during midwinter. In general, small statured woody plants have a high risk of frost damage in spring, particularly when these plants have partially deacclimated or never developed full hardiness due to snow cover, and then lose their snow cover in late winter (Sakai and Larcher, 1987; Havranek and Tranquillini, 1995; Körner, 2012). Severe night frosts can occur in the subalpine environment during this time of the year and

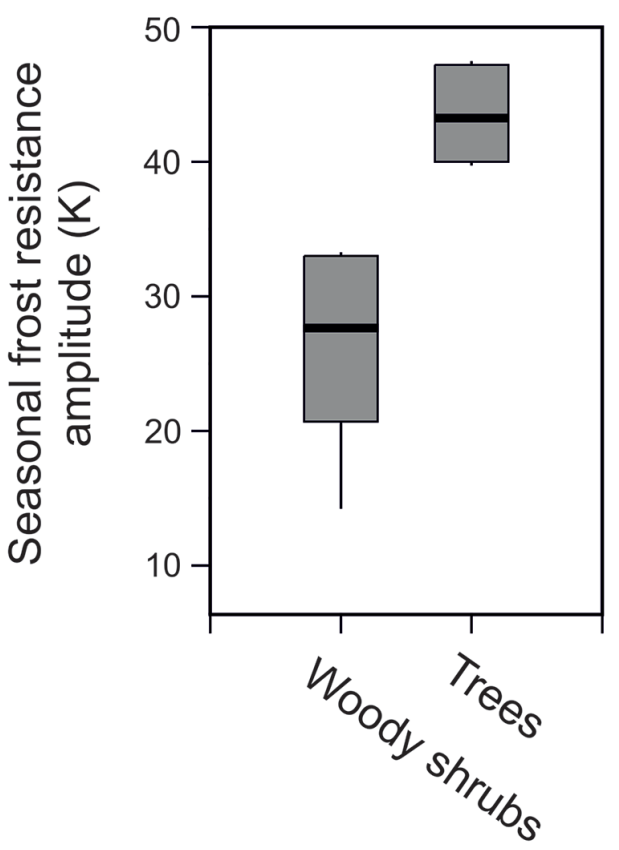

FIGURE 7 | Seasonal amplitude of frost resistance (K) in evergreen leaves of trees (Picea abies, Pinus cembra) compared to six woody alpine shrubs (Pinus mugo, Arctostaphylosuva-ursi, Rhododendron ferrugineum, Vaccinium vitis-idea, Loiseleuria procumbens, Calluna vulgaris) under natural frost hardening in the treeline ecotone on Mt. Patscherkofel.

the loss of snow cover along with their lower level of frost resistance makes them especially vulnerable to freezing injury. In such a scenario, the potential risk of frost damage will largely depend on the species-specific ability to rapidly reacclimate. The ability to reacclimate may be reduced in woody plants at this time of year due to changes in the physiology of these plants induced by their exposure to longer photoperiods (Schwarz, 1970). Little knowledge exists for most woody plant species with respect to their ability to reacclimate or the rate at which they can reacclimate.

To examine the rate of frost re-hardening (reacclimation) in spring, $R$. ferrugineum shrubs were exposed in situ to controlled night frosts close to the lowest temperature that did not induce frost damage ( $\mathrm{LT}_{0}$; Neuner et al., 1999b). This experimental protocol was used to determine the potential frost re-hardening response under otherwise completely natural environmental conditions (Neuner et al., 1999b). After a lag period of three days, during which no significant increase in frost resistance was observed, frost resistance suddenly increased by $5.9^{\circ} \mathrm{C}$ within $24 \mathrm{~h}$. Although a total gain in frost hardiness between 7.8 and $9.2^{\circ} \mathrm{C}$ was possible, the retarded response appeared too slow to offer sufficient frost protection from a sudden frost event. In a recent study, Wheeler et al. (2014) also reported that earlier snow-melt may increase the risk of a lethal spring freezing event for less frost-resistant alpine dwarf shrubs, such as V. myrtillus and V. uliginosum. This is in line with observations on subarctic heath that readily responds to increased temperatures by frost dehardening (deacclimation; Bokhorst et al., 2010). 
Table 3 | Midwinter frost resistance ( $\left.\mathrm{LT}_{50}\right)$ measured for leaves collected at either $600 \mathrm{~m}$ or $1950 \mathrm{~m}$, and either below a thick snow cover or from exposed shoots on 17.1.2014.

\begin{tabular}{llll}
\hline Plant species & $\begin{array}{l}\mathbf{1 9 5 0} \mathbf{m} \\
\text { No snow protection } \\
\left.\mathbf{( L T}_{\mathbf{5 0}} \pm \mathbf{S D} ;{ }^{\circ} \mathbf{C}\right)\end{array}$ & $\begin{array}{l}\mathbf{1 9 5 0} \mathbf{~ m} \\
\text { Snow protection } \\
\left.\mathbf{( L T}_{\mathbf{5 0}} \pm \mathbf{S D} ;{ }^{\circ} \mathbf{C}\right)\end{array}$ & $\begin{array}{l}\mathbf{6 0 0} \mathbf{m} \\
\text { No snow protection } \\
\left.\mathbf{( L T}_{\mathbf{5 0}} \pm \mathbf{S D} ;{ }^{\circ} \mathbf{C}\right)\end{array}$ \\
\hline A. uva-ursi & $-41,6 \pm 10,1$ & $-34,3 \pm 2,4$ & - \\
P. abies & $-43,4 \pm 6,3$ & $-37,3 \pm 5,4$ & $-33,0 \pm 4,4$ \\
V. vitis-idea & $-42,4 \pm 5,6$ & $-29,4 \pm 4,0$ & $-23,5 \pm 1,2$
\end{tabular}

Trees may also be at risk of frost damage in the spring. In situ exposure of $P$. cembra to increased air temperatures in late winter induced rapid deacclimation (Buchner and Neuner, 2011). Similar reports exist for other woody species that also respond to warmer spring temperatures with an untimely reduction in frost resistance (Picea rubens: Strimbeck et al., 1995; P. sylvestris: Repo et al., 1996; Vaccinium myrtillus: Taulavuori et al., 1997; Betula pubescens: Taulavuori et al., 2004). Premature frost dehardening of $P$. cembra in late winter, induced by artificially increased air or soil temperatures, reduced the frost resistance of buds to $-10.2^{\circ} \mathrm{C}\left(\mathrm{LT}_{50}\right)$ while the untreated controls still had an $\mathrm{LT}_{50}$ of $-32.6^{\circ} \mathrm{C}$ (Buchner and Neuner, 2011). During episodes of low temperature in April at the alpine timberline, air temperature minima can still drop down to $-16.3^{\circ} \mathrm{C}$ (30 years temperature record; ZAMG). This temperature would be sufficiently low enough to cause significant frost damage to P. cembra. Warmer temperatures in late winter will also induce earlier bud burst in P. cembra (Buchner and Neuner, 2011) which must be considered a critical concern for a species that currently escapes frost damage during budbreak and the initial growth of current year shoots by delaying budbreak until the risk of significant frost events is low.

\section{STEMS}

The bark tissue of temperate woody plants typically exhibit freezing tolerance, undergoing equilibrium freezing when ice forms in its tissues and the temperature continues to drop (Sakai and Larcher, 1987). In contrast, xylem tissues can exhibit different responses to freezing temperatures. Xylem parenchyma cells (XPC) are the only living cells in the xylem. In some species, XPCs have been shown to survive freezing temperatures by deep supercooling down to $-40^{\circ} \mathrm{C}$ or even lower (Sakai and Larcher, 1987). With the exception of Arctostaphylos uva-ursi, where XPCs were reported to exhibit deep supercooling (Becwar etal., 1981), the mechanism of frost survival of xylem tissues of European alpine woody plants is not known. In a survey of woody treeline species in Colorado, the XPCs of some species in genera such as Pinus, Picea, Abies, and Juniperus, exhibited supercooling. This could be indicative for their European counterparts but remains to be elucidated. Freezing of water in the xylem tissue can also have secondary freezing effects that are not discussed in the present review, namely freeze-induced xylem embolism (Sperry et al., 1994).

\section{CONCLUSION}

Various frost resistance mechanisms have evolved in alpine woody plants. In addition to tolerating the presence of ice in their tissues and the concomitant dehydrative stress, some tissues and organs that rely on freezing avoidance can also be found. In many species, the mechanism by which they survive freezing temperatures is unknown, and thus represents a fertile area for future research.

In freezing sensitive tissues, such as reproductive shoots and buds, and young developing shoots, escape from frost damage is only possible by preventing the initial formation of ice (freeze avoidance). This can be realized in woody plants by a structural ice barrier that prevents ice propagation from other tissues into the freezing sensitive tissues, and the absence or inhibition of ice nucleation active substances in the freezing sensitive tissues or organs which would allow them to supercool. The specific features of structural ice barriers still remain to be elucidated. Outside of a direct role for the absence of mature vascular tissue which would act as a conduit for the spread of ice, the determining factor(s) involved in the prevention of the spread of ice into buds and reproductive shoots is still an open question but may involve specific anatomical and biochemical (cell wall impregnation and porosity, dry tissue regions) adaptations. Additionally, hardly any attention has focused on the presence of metabolites in supercooled tissues which may facilitate their ability to remain in an ice free state.

Woody alpine species can experience frost damage throughout the whole year. In summer, the most frost susceptible organs of woody species are reproductive shoots $\left(-4.6^{\circ} \mathrm{C}\right)$; followed by immature leaves $\left(-5.0^{\circ} \mathrm{C}\right)$, fully expanded leaves $\left(-6.6^{\circ} \mathrm{C}\right)$, vegetative buds $\left(-7.3^{\circ} \mathrm{C}\right)$, and xylem tissue $\left(-10.8^{\circ} \mathrm{C}\right)$. These levels of freezing resistance can be insufficient to survive the potential frost events that can occur in June. The severity and frequency of freezing temperatures significantly increases with increasing elevation. Perhaps it is the most frost-susceptible parts with hardly any freezing resistance that define the upper limit of elevation for the distribution of some woody species. Intriguingly, woody species that inhabit the highest elevations bury their stems in the soil, perhaps for a better protection against the impact of summer frost events.

Differences in frost resistance mechanisms and the maximum level of freezing resistance of various plant tissues and organs within the same plant stresses the importance of studying whole plants rather than extrapolating data obtained from plant parts. Most importantly, this emphasizes the need to study plants under conditions that are as close to natural as possible. Field studies 
that simulate frosts, or even better are conducted under natural frosts, are still rare. This can be partially attributed to the difficulties involved in conducting such studies. Their ecological significance, however, is invaluable as the whole plant; including all tissues, has an impact on the obtained results. Only the ability of plants to survive and recuperate under natural and complex environmental conditions will provide a realistic picture of the potential frost survival of a species at a certain site.

Mean frost resistance in winter is lowest in reproductive buds $\left(-23.4^{\circ} \mathrm{C}\right)$, that without snow cover may not escape frost damage in all winters. In contrast, the freezing resistance of all other organs exhibit greater levels of freezing resistance that vary in a speciesspecific manner (vegetative buds: -30 to $-50^{\circ} \mathrm{C}$, leaves: -25 to $-58.5^{\circ} \mathrm{C}$, stem: -30 to $-70^{\circ} \mathrm{C}$ ). Seasonal data on frost resistance of leaves of woody alpine species at treeline under natural frost hardening indicate that a sufficiently high level of frost resistance is attained for trees in midwinter to allow them to survive naturally occurring winter freezing temperatures. Leaves of some shrubs, however, may need to rely on the thermal insulation provided by snow cover.

Regarding the risk of frost damage to woody plants, seasonality is a significant factor, particularly given the projected scenarios associated with climate change (Hänninen and Tanino, 2011). The transition period from endo- and ecodormancy in winter and early spring, to the active growing period in summer, is of special concern. Till now, the dynamics of seasonal and short-term frost hardening has been studied nearly exclusively in evergreen leaves; scarce knowledge exists for other organs and tissues. Phenological data in Europe (1971-2000) has indicated that 78\% of all leafing, flowering, and fruiting records have advanced and that the average advance of spring has been 2.5 days decade ${ }^{-1}$ (Menzel et al., 2006). Alteration in the timing of bud burst may result in a species being less well adapted to the local temperature environment (Kramer, 1995). This includes an increased probability of spring frost damage (Murray et al., 1989; Hänninen, 1991, 1996; Kramer, 1994). Premature deacclimation (frost dehardening), once photoperiod signals the approach of spring and chilling requirements are fulfilled, is a realistic probability for alpine tree species ( $P$. cembra, Buchner and Neuner, 2011). Woody shrubs, receiving thermal insulation from an early snow fall, harden to a lesser extent, and can occasionally deacclimate below the snow cover. The ability to reacclimate and the speed at which a species can reacclimate in response to unfavorable temperatures is an important parameter that remains virtually unexplored (Neuner et al., 1999b). Generally, the dynamics of the processes that fine-tune the level of frost hardiness to prevailing environmental conditions are only understood to a limited extent. If future scenarios of climate change occur as predicted by Katz and Brown (1992), where in addition to global warming, the frequency of unpredictable extreme temperature events increases, the ability of plants to reacclimate in a timely manner or resist budbreak may be even more critical in the future.

\section{ACKNOWLEDGMENTS}

Edith Kuprian and Ramona Miller are gratefully acknowledged for their technical assistance and help in preparing IDTA images used in the presented figures. This research was funded by the FWF project P23681-B16.

\section{REFERENCES}

Bannister, P., and Neuner, G. (2001). "Frost resistance and the distribution of conifers," in Conifer Cold Hardiness, eds F. J. Bigras and S. J. Colombo (Dordrecht: Kluwer Academic Publisher), 3-22. doi: 10.1007/978-94-0159650-3_1

Becwar, M. R., Rajashekar, C., Hansen Bistrow, K. J., and Burke, M. J. (1981). Deep undercooling of tissue water and winter hardiness limitations in timberline flora. Plant Physiol. 68, 111-114. doi: 10.1104/pp. 68.1.111

Bokhorst, S., Bjerke, J. W., Davey, M. P., Taulavuori, K., Taulavuori, E., Laine, K., et al. (2010). Impacts of extreme winter warming events on plant physiology in a sub-arctic heath community. Physiol. Plant 140, 128-140. doi: 10.1111/j.13993054.2010.01386.x

Buchner, O., and Neuner, G. (2009). A low temperature freezing system to study effects of freezing temperatures down to $-70^{\circ} \mathrm{C}$ on trees in situ. Tree Physiol. 29, 313-320. doi: 10.1093/treephys/tpn038

Buchner, O., and Neuner, G. (2011). Winter frost resistance of Pinus cembra measured in situ at the alpine timberline as affected by temperature conditions. Tree Physiol. 31, 1217-1227. doi: 10.1093/treephys/tpr103

Byars, S. G., Papst, W., and Hoffmann, A. A. (2007). Local adaptation and cogradient selection in the 452 alpine plant, Poahiemata, along a narrow altitudinal gradient. Evolution 61, 2925-2941. doi: 10.1111/j.1558-5646.2007.00248.x

Carter, J., Brennan, R., and Wisniewski, M. (2001). Patterns of ice formation and movement in black currant. HortScience 36, 855-859.

Christersson, L., von Fircks, H., and Sihe, Y. (1987). "Damage to conifer seedlings by summer frost and winter drought," in Plant Cold Hardiness and Freezing Stress, eds P. H. Li and R. Alan (New York: Liss Inc), 203-210.

Frederiks, T. M., Christopher, J. T., Harvey, G. L., Sutherland, M. W., and Borrell, A. K. (2012). Current and emerging screening methods to identify post-heademergence frost adaptation in wheat and barley. J. Exp. Bot. 63, 5405-5416. doi: $10.1093 /$ jxb/ers215

Grabherr, G., Gottfried, M., Gruber, A., and Pauli, H. (1995). "Patterns and current changes in alpine plant diversity," in Arctic and Alpine Plant Diversity: Patterns, Causes and Ecosystem Consequences, Ecological Studies, Vol. 113, eds F. S. Chapin III and C. Körner (Berlin: Springer), 167-181.

Gross, M., Rainer, I., and Tranquillini, W. (1991). Über die frostresistenz der fichte mit besonderer berücksichtigung der zahl der gefrierzyklen und der geschwindigkeit der temperaturänderung beim frieren und auftauen. Forstw. Cbl. 110, 207-217. doi: 10.1007/BF02741255

Hacker, J., Ladinig, U., Wagner, J., and Neuner, G. (2011). Inflorescences of alpine cushion plants freeze autonomously and may survive subzero temperatures by supercooling. Plant Sci. 180, 149-156. doi: 10.1016/j.plantsci.2010.07.013

Hacker, J., and Neuner, G. (2007). Ice propagation in plants visualized at the tissue level by IDTA (infrared differential thermal analysis). Tree Physiol. 27, 1661-1670. doi: $10.1093 /$ treephys/27.12.1661

Hacker, J., and Neuner, G. (2008). Ice propagation in dehardened alpine plant species studied by infrared differential thermal analysis (IDTA). Arc. Antarc. Alp. Res. 40, 660-670. doi: 10.1657/1523-0430(07-077)[HACKER]2.0.CO;2

Hacker, J., Spindelböck, J., and Neuner, G. (2008). Mesophyll freezing and effects of freeze dehydration visualized by simultaneous measurement of IDTA and differential imaging chlorophyll fluorescence. Plant Cell Environ. 31, 1725-1733. doi: 10.1111/j.1365-3040.2008.01881.x

Hadley, J. L., and Smith, W. K. (1987). Influence of krummholz mat microclimate on needle physiology and survival. Oecologia 73, 82-90. doi: 10.1007/BF00376981

Hänninen, H. (1991). Does climate warming increase the risk in frost damage in Northern trees? Plant Cell Environ. 14, 449-454. doi: 10.1111/j.13653040.1991.tb01514.x

Hänninen, H. (1996). Effects of climatic warming on northern trees: testing the frost damage hypothesis with meteorological data from provenance transfer experiments. Scand. J. Res. 11, 17-25. doi: 10.1080/02827589609382908

Hänninen, H., and Tanino, K. (2011). Tree seasonality in a warming climate. Trends Plant Sci. 16, 412-416. doi: 10.1016/j.tplants.2011.05.001

Havranek, W. M., and Tranquillini, W. (1995). "Physiological processes during winter dormancy and their ecological significance," in Ecophysiology of Coniferous Forests, eds W. K. Smith and T. M. Hinckley (San Diego: Academic Press), 95-124. 
Ide, H., Price, W. S., Arata, Y., and Ishikawa, M. (1998). Freezing behaviors in leaf buds of cold-hardy conifersvisualized by NMR microscopy. Tree Physiol. 18, 451-458. doi: 10.1093/treephys/18.7.451

Ishikawa, M., Price, W. S., Ide, H., and Arata, Y. (1997). Visualization of freezing behaviors in leaf and flower buds of full-moon maple by nuclear magnetic resonance microscopy. Plant Physiol. 115, 1515-1524.

Ishikawa, M., and Sakai, A. (1982). "Characteristics of freezing avoidance in comparison with freezing tolerance: a demonstration of extra-organ freezing," in Plant Cold Hardiness and Freezing Stress, eds P. H. Li and A. Sakai (New York, NY: Academic Press), 325-340.

Jordan, D. N., and Smith, W. K. (1994). Energy balance analysis of nighttime leaf temperatures and frost formation in a subalpine environment. J. Agri. For Meteorol. 71, 359-372. doi: 10.1016/0168-1923(94)90020-5

Katz, R. W., and Brown, B. G. (1992). Extreme events in a changing climate: variability is more important than averages. Climate Change 21, 289-302. doi: 10.1007/BF00139728

Kerner, A. (1869). "Die Abhängigkeit der Pflanzengestalt von Klima und Boden," in Festschrift der 43. Jahresversammlung Deutscher Naturforscher und Ärzte (Innsbruck, TY: Wagner), 29-45.

Körner, C. (2003). Alpine Plant Life. Heidelberg: Springer.

Körner, C. (2011). Coldest places on earth with angiosperm plant life. Alp. Bot. 121, 11-22. doi: 10.1007/s00035-011-0089-1

Körner, C. (2012). Alpine Treelines. Basel: Springer. doi: 10.1007/978-3-0348-0396-0

Kramer, K. (1994). A modelling analysis of the effects of climatic warming on the probability of spring frost damage to tree species in the Netherlands and Germany. Plant Cell Environ. 17, 367-377. doi: 10.1111/j.1365-3040.1994.tb00305.x

Kramer, K. (1995). Phenotypic plasticity of the phenology of seven European tree species in relation to climatic warming. Plant Cell Environ. 18, 93-104. doi: 10.1111/j.1365-3040.1995.tb00356.x

Kuhn, M. (2012). "Rain and snow at high elevation," in Plants in Alpine Regions: Cell Physiology of Adaptation and Survival Strategies, ed. C. Lütz (Vienna: Springer), 1-10. doi: 10.1007/978-3-7091-0136-0_1

Kuprian, E., Briceno, V., Wagner, J., and Neuner, G. (2014). Ice barriers promote supercooling and prevent frost injury in reproductive buds, flowers and fruits of alpine dwarf shrubs throughout the summer. Env. Exp. Bot. 106, 4-12. doi: 10.1016/j.envexpbot.2014.01.011

Ladinig, U., Hacker, J., Neuner, G., and Wagner, J. (2013). How endangered is sexual reproduction of high-mountain plants by summer frosts? - Frost resistance, frequency of frost events and risk assessment. Oecologia 171, 743-760. doi: $10.1007 / \mathrm{s} 00442-012-2581-8$

Landolt, E. (1992). Unsere Alpenflora. Stuttgart: Fischer.

Larcher, W. (1985). "Kälte und Frost," in Handbuch der Pflanzenkrankheiten, ed. P. Sorauer (Berlin: Parey), 107-320.

Larcher, W., and Wagner, J. (2004). Lebensweise der alpenrosen in ihrer umwelt: 70 jahre ökophysiologische forschung in innsbruck. Ber. Nat. Med. Ver. Innsbruck 91, 251-291.

Larcher, W., and Wagner, J. (2009). High mountain bioclimate: temperatures near the ground recorded from the timberline to the nival zone in the central alps. Contrib. Nat. Hist. Bern 12, 857-874.

Matuszkiewicz, W. (1977). "Spät- und frühföste als standortsökologischer faktor in den waldgesellschaften des bialowieza nationalparks (Polen)," in Vegetation und Klima, ed. H. Dierschke (Vaduz: Cramer), 195-233.

Menzel, A., Sparks, T. H., Estrella, N., Koch, E., Aasa, A., Ahas, R., et al. (2006). European phenologicalresponse to climate change matches the warming pattern. Global Change Biol. 12, 1969-1976. doi: 10.1111/j.1365-2486.2006.01193.x

Murray, M. B., Cannell, M. G. R., and Smith, R. T. (1989). Date of bud burst of fifthteen tree species in Britain following climatic warming. J. Appl. Ecol. 26, 693-700. doi: 10.2307/2404093

Neuner, G., Ambach, D., and Aichner, K. (1999a). Impact of snow cover on photoinhibition and winter desiccation in evergreen Rhododendron ferrugineum L. leaves during subalpine winter. Tree Physiol. 19, 725-732. doi: 10.1093/treephys/19.11.725

Neuner, G., Ambach, D., and Buchner, O. (1999b). Readiness to frost harden during the dehardening period measured in situ in leaves of Rhododendron ferrugineum L. at the alpine timberline. Flora 194, 289-296.

Neuner, G. (2007). "Frost resistance at the upper timberline," in Trees at their Upper Limit, eds G. Wieser, and M. Tausz (Berlin: Springer), 171-180. doi: 10.1007/14020-5074-7_10
Neuner, G., and Beikircher, B. (2010). Critically reduced frost resistance of Picea abies during sprouting in relation to cytological changes. Protoplasma 243, 145152. doi: 10.1007/s00709-009-0052-9

Neuner, G., and Buchner, O. (2012). "Dynamic of tissue heat tolerance and thermotolerance of PS II in alpine plants," in Plants in Alpine Regions: Cell Physiology of Adaptation and Survival Strategies, ed. C. Lütz (Vienna: Springer), 61-74.

Neuner, G., and Hacker, J. (2012). "Ice formation and propagation in alpine plants," in Plants in Alpine Regions: Cell Physiology of Adaptation and Survival Strategies, ed. C. Lütz (Vienna: Springer), 163-174.

Neuner, G., Xu, B., and Hacker, J. (2010). Velocity and pattern of ice propagation and deep supercooling in woody stems of Castanea sativa, Morusnigra and Quercusrobur measured by IDTA. Tree Physiol. 30, 1037-1045. doi: 10.1093/treephys/tpq059

Pearce, R. S. (1999). Molecular analysis of acclimation to cold. Plant Growth Reg. 29, 47-76. doi: 10.1023/A:1006291330661

Perkins, T. D., and Adams, G. T. (1995). Rapid freezing induces winter injury symptomatology in red spruce foliage. Tree Physiol. 15, 259-266. doi: 10.1093/treephys/15.4.259

Perkins, T. D., Adams, G. T., and Klein, R. M. (1991). Desiccation or freezing? Mechanisms of winter injury to red spruce foliage. Am. J. Bot. 78, 1207-1217. doi: $10.2307 / 2444925$

Pisek, A., and Schiessl, R. (1947). Die Temperaturbeeinflußbarkeit der frosthärte von nadelhölzern und zwergsträuchern an der alpinen waldgrenze. Ber. Nat. Med. Ver. Innsbruck 47, 33-52.

Pramsohler, M., and Neuner, G. (2013). Dehydration and osmotic adjustment in apple stem tissue during winter as it relates to the frost resistance of buds. Tree Physiol. 33, 807-816. doi: 10.1093/treephys/tpt057

Rajashekar, C., and Burke, M. J. (1978). "The occurrence of deep supercooling in the genera Pyrus, Prunus and Rosa. A preliminary report," in Plant Cold Hardiness and Freezing Stress, eds P. H. Li and A. Sakai (New York: Academic Press), 213-225. doi: 10.1016/B978-0-12-447650-9.50019-8

Repo, T., Hänninen, H., and Kellomäki, S. (1996). The effects of long-term elevation of air temperature and $\mathrm{CO} 2$ on the frost hardiness of Scots pine. Plant Cell Environ. 19, 209-216. doi: 10.1111/j.1365-3040.1996.tb00242.x

Sakai, A. (1978). Low temperature exotherms of winter buds of hardy conifers. Plant Cell Physiol. 19, 1439-1446.

Sakai, A., and Larcher, W. (1987). Frost Survival of Plants: Responses and Adaptation to Freezing Stress. Ecological Studies, Vol. 62. Berlin: Springer. doi: 10.1007/978-3642-71745-1

Sakai, A., and Okada, S. (1971). Freezing resistance of conifers. Silvae Genet. 20, 91-97.

Schwarz, W. (1970). Der einfluß der photoperiode auf das austreiben, die frosthärte und die hitzeresistenz von zirben und alpenrosen. Flora 159, 258-285.

Sperry, J. S., Nichols, K. L., Sullivan, J. E. M., and Eastlack, S. E. (1994). Xylem embolism in ring-porous, diffuse-porous, and coniferous trees of Northern Utah and interior Alaska. Ecology 75, 1736-1752. doi: 10.2307/19 39633

Strimbeck, G. R., Schaberg, P. G., DeHayes D. H., Shane J. B., and Hawley, G. J. (1995). Midwinter dehardening of montane red spruce during a natural thaw. Can. J. For. Res. 25, 2040-2044. doi: 10.1139/x95-221

Taschler, D., Beikircher, B., and Neuner, G. (2004). Frost resistance and ice nucleation in leaves of five woody timberline species measured in situ during shoot expansion. Tree Physiol.24, 331-337. doi: 10.1093/treephys/24. 3.331

Taschler, D., and Neuner, G. (2004). Summer frost resistance and freezing patterns measured in situ in leaves of major alpine plant growth forms in relation to their upper distribution boundary. Plant Cell Environ. 27, 737-746. doi: 10.1111/j.1365-3040.2004.01176.x

Taulavuori, K., Laine, K., Taulavuori, E., Pakonen, T., and Saari, E. (1997). Accelerated dehardening in Bilberry (Vaccinum myrtillus L.) induced by a small elevation in air temperature. Environ. Poll. 98, 91-95. doi: 10.1016/S0269-7491(97) 00115-2

Taulavuori, K. M. J., Taulavuori, E. B., Skre, O., Nilsen, J., Igeland, B., and Laine, K. M. (2004). Dehardening of mountain birch (Betula pubescenssspczerepanovii) ecotypes at elevated winter temperatures. New Phytol. 162, 427-436. doi: $10.1111 /$ j.1469-8137.2004.01042.x 
Theurillat, J.-P., and Guisan, A. (2001). Potential impact of climate change on vegetation in the European546 alps: a review. Climatic Change 50, 77-109. doi: 10.1023/A:1010632015572

Thomashow, M. F. (1999). Plant cold acclimation: Freezing tolerance genes and regulatory mechanisms. Ann. Rev. Plant Physiol. 50, 571-599. doi: 10.1146/annurev.arplant.50.1.571

Tranquillini,W. (1958). Die Frosthärte der Zirbe unter besonderer Berücksichtigung autochthoner und aus Forstgärten stammender Jungpflanzen. Forstw. Centralbl. 77, 65-128. doi: 10.1007/BF01815139

Tranquillini, W. (1979). Physiological Ecology of the Alpine Timberline: Tree Existence at High Altitude with Special Reference to the European Alps. Ecology Studies, Vol. 31. Berlin: Springer. doi: 10.1007/978-3-642-67107-4

Ulmer, W. (1937). Über den Jahresgang der Frosthärte einiger immergrüner Arten der alpinen Stufe, sowie Zirbe und Fichte. Jb. Wiss. Bot. 84,553-592.

Wheeler, J. A., Hoch, G., Cortés, A. J., Sedlacek, J., Wipf, S., and Rixen, C. (2014). Increased spring freezing vulnerability for alpine shrubs under early snowmelt. Oecologia 175, 219-229. doi: 10.1007/s00442-013-2872-8

Wisniewski, M., Gusta, L., and Neuner, G. (2014). Adaptive mechanisms of freeze avoidance in plants. A brief update. Env. Exp. Bot. 99, 133-140. doi: 10.1016/j.envexpbot.2013.11.011

Workmaster, B. A. A., Palta, J. P., and Wisniewski, M. (1999). Ice nucleation and propagation in cranberry uprights and fruit using infrared video thermography. J. Am. Soc. Hort. Sci. 124, 619-625.
Xin, Z., and Browse, J. (2000). Cold comfort farm: the acclimation of plants to freezing temperatures. Plant Cell Environ. 23, 893-902. doi: 10.1046/j.13653040.2000.00611.x

Zwiazek, J. J. R. S., Croser, C., Hansen, J., and Beck, E. (2001). "Biochemicaland biophysical changes in relation to cold hardiness," in ConiferCold Hardiness, eds F. J. Bigras and S. J. Colombo (Dordrecht: Kluwer Academic Publisher),165-186.

Conflict of Interest Statement: The author declares that the research was conducted in the absence of any commercial or financial relationships that could be construed as a potential conflict of interest.

Received: 29August 2014; accepted: 03 November 2014; published online: 01 December 2014.

Citation: Neuner G (2014) Frost resistance in alpine woody plants. Front. Plant Sci. 5:654. doi: 10.3389/fpls.2014.00654

This article was submitted to Functional Plant Ecology, a section of the journal Frontiers in Plant Science.

Copyright (c) 2014 Neuner. This is an open-access article distributed under the terms of the Creative Commons Attribution License (CC BY). The use, distribution or reproduction in other forums is permitted, provided the original author(s) or licensor are credited and that the original publication in this journal is cited, in accordance with accepted academic practice. No use, distribution or reproduction is permitted which does not comply with these terms. 